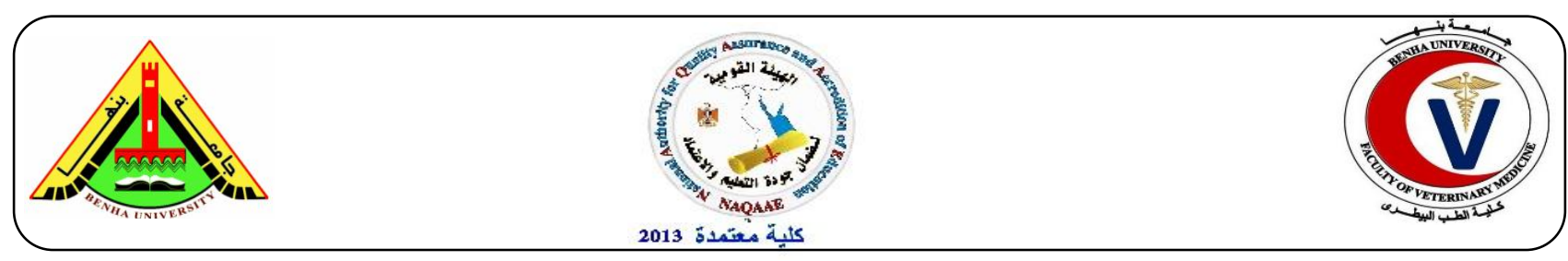

\title{
The Bacteriological Quality of Some Chicken Meat Products
}

\author{
Ibrahim, H.M. ${ }^{\text {a }}$, Hassan, M.A. ${ }^{a}$,Amin, R.A. ${ }^{a}$, Shawqy, N.A.b and Elkoly, R.L.b \\ ${ }^{a}$ Food hygiene Dep., Fac. Vet. Med., Benha Univ. \\ ${ }^{\mathrm{b}}$ Animal Health research institute, Shebin el koom branch.
}

\section{A B S T R A C T}

The chicken meat is one of the main sources of animal protein all over the world; and the volume of their production, marketing and consumption is increasing to satisfy the public demand worldwide within the last decades (Lyon et al., 2007). A total of 90 random samples of chicken meat products (nuggets, luncheon and frozen shawerma) (25 g, 30 of each), were collected from different supermarkets at El- Menufia governorates. The mean values of aerobic plate, coliforms and Staphylococci counts were $1.99 \times 10^{5} \pm 0.62 \times 10^{5}, 1.14 \times 10^{3} \pm 0.35 \times 10^{3}$ and $4.3 \times 10^{2} \pm 1 \times 10^{2}(\mathrm{cfu} / \mathrm{g})$ in chicken luncheon, $3.83 \times 105 \pm 9.6 \times 10^{4}, 5.0 \times 10^{3} \pm 1.2 \times 10^{3}, 1.6 \times 10^{3} \pm 0.42 \times 10^{3} \mathrm{cfu} / \mathrm{g}$, in chicken nuggets and $2.77 \times 10^{6} \pm 1.4 \times 10^{6}, 6.33 \times 10^{3} \pm 1.7 \times 10^{3}$ and $1.97 \times 10^{3} \pm 0.52 \times 10^{3}(\mathrm{cfu} / \mathrm{g})$ in shawerma, respectively. The incidence of Staphylococcus aureus in the examined samples of chicken luncheon, nuggets, and shawerma wad 7 (23.3\%), 9 (30\%) and 14 (46.6\%), While the incidence of E. coli was $4(13.3 \%), 5(16.6 \%)$ and 7 (23.3\%), in the examined samples of luncheon, nuggets, and shawerma, respectively. Most of the examined chicken meat products were contaminated with $E$. coli and Staphylococcus aureus and this is considered objectionable.

Key words: Chicken meat products, APC, E.coli, S.aureus.

(http://www.bvmj.bu.edu.eg)

(BVMJ-35(1): 50-57, 2018)

\section{INTRODUCTION}

In Egypt, chicken meat products are gaining popularity because they represent quick easily prepared meat meals and solve the problem of the shortage in fresh meat of high price which is not within the reach of large numbers of families with limited income.

The chicken meat is one of the main sources of animal protein all over the world; and the volume of their production, marketing and consumption is increasing to satisfy the public demand worldwide within the last decades (Lyon et al., 2007).
In processing plants, contamination of poultry meat products can occur throughout processing, packaging and storage until the product is sufficiently cooked and consumed (Mensah et al., 2002).

In recent years, food borne infections and intoxication have assumed significance as a health hazard. Epidemiological reports suggest that chicken meat is still the primary cause of human food poisoning (Ruban and Fairoze, 2011).

Amongst the food borne pathogens, Staphylococcus aureus and E. coli are the most common and frequent pathogens 
responsible for food poisoning and food related infections (Pires et al., 2012).

Staphylococcus aureus is an important pathogen and has been indicated as the fifth causative agent of food-borne human illness throughout the world. Staphylococcal enterotoxins (SEs) are toxic compounds excreted mainly by strains of Staphylococcus aureus (Soriano et al., 2012).

E. coli is a major component of the normal intestinal flora of human and other mammals which are usually harmless to the host and only cause diseases in immunocompromised hosts or when the gastrointestinal barriers are breached. However, some specific E.coli strains represent primary pathogens with enhanced potential to cause disease after acquiring specific virulence attributes (Li et al., 2005).

Therefore, the present study was planned out to throw a light on the bacteriological quality of some chicken meat products and the isolation, identification and serotyping of some food poisoning microorganisms mainly E.coli and Staphylococcus aureus in locally manufactured chicken meat products (luncheon, nuggets and shawerma)

\section{MATERIALS AND METHODS}

\subsection{Collection of samples:}

A total of 90 random samples of chicken meat products classified into chicken nuggets, chicken luncheon and frozen chicken shawerma $(25 \mathrm{~g}, 30$ of each) which were collected from different supermarkets at ElMenufia governorates. The collected samples were transferred directly to the laboratory in an ice box under complete aseptic conditions

\section{RESULTS}

It is evident from the results recorded in Table (1) that the APC (cfu/g) in the examined samples of chicken meat products varied from $6.0 \times 10^{3}$ to $1.7 \times 10^{6}$ with a mean value of $1.99 \times 10^{5} \pm 0.62 \times 10^{5} \mathrm{cfu} / \mathrm{g}$ in without undue delay and then subjected to the following examination.

\subsection{Aerobic Plate Count:}

It carried out according to (APHA, 1992). Plate count agar media is used and incubation at $37^{\circ} \mathrm{C}$ for 48 hours.

\subsection{Coliforms count:}

It carried out according to (ICMSF, 1996). Violet red bile (VRB) agar was used and incubation at $37^{\circ} \mathrm{C}$ for 24 hours.

\subsection{Staphylococci count:}

It carried out according to (ICMSF, 1996). Baired Parker agar media was used and incubation at $37^{\circ} \mathrm{C}$ for 48 hours.

\subsection{Isolation and Identification of} Staphylococcus aureus

It carried out according to (ICMSF, 1996). Baired Parker agar media was used and $37^{\circ} \mathrm{C}$ for 48 hours. Suspected colonies of Staph. aureus appeared as black shiny with narrow white margin and surrounded by clear zone.

2.6 Isolation and identification of E. coli.

It carried out according to (APHA, 1992). Enrichment on Macckonkey broth tube supplemented with inverted Durham's tubes and incubated at $37^{\circ} \mathrm{C} / 24-48 \mathrm{hrs}$, then $1 \mathrm{ml}$ of positive tubes (showed acid and gas production) was taken to MacConkey broth tube with inverted Durham's tubes and incubated at $44 \pm 0.5^{\circ} \mathrm{C} / 48 \mathrm{hrs}$. Tubes showing gas production and change are positive for true fecal type E.coli. Selective Plating on Eosin methylene blue (EMB) agar, incubated at $37^{\circ} \mathrm{C} / 24 \mathrm{hrs}$. Typical colonies are greenish metallic with dark purple center.

\subsection{Statistical Analysis (SPSS, Version 16).}

chicken luncheon, $9.1 \times 10^{3}$ to $1.9 \times 10^{6}$ with a mean value of $3.83 \times 10^{5} \pm 9.6 \times 10^{4} \mathrm{cfu} / \mathrm{g}$ in chicken nuggets, and $2.1 \times 10^{4}$ to $3.5 \times 10^{7}$ with a mean value of $2.77 \times 10^{6} \pm 1.4 \times 10^{6} \mathrm{cfu} / \mathrm{g}$ in half cooked chicken shawerma.

Clearly, $80 \%, 93.3 \%$ and $100 \%$ of the examined samples of chicken luncheon, 
nuggets and shawerma were unaccepted based on their limits of APC according to (EOS, 2005) which recommend that APC not exceed $10^{4} \mathrm{cfu} / \mathrm{g}$ as recorded in Table (2).

From the obtained results recorded in Table (3), it is clear that Coliform count in the examined samples was varied $1.0 \times 10^{2}$ to $9.3 \times 10^{3}$ with a mean value of $1.14 \times 10^{3} \pm$ $0.35 \times 10^{3} \mathrm{cfu} / \mathrm{g}$ in chicken luncheon, $1.0 \times 10^{2}$ to $2.3 \times 10^{4}$ with a mean value of $5.0 \times 10^{3} \pm 1.2$ $\times 10^{3} \mathrm{cfu} / \mathrm{g}$ in chicken nuggets, and $1.0 \times 10^{2}$ to $3.5 \times 10^{4}$ with a mean value of $6.33 \times 10^{3} \pm$ $1.7 \times 10^{3} \mathrm{cfu} / \mathrm{g}$ in half cooked chicken shawerma, respectively.

Nearly about $63.3 \%, 80 \%$ and $96.7 \%$ of the examined samples of chicken luncheon, nuggets and shawerma were unaccepted based on their limits of Coliforms according to (EOS, 2005) which recommend that coliforms count not exceed $10^{2} \mathrm{cfu} / \mathrm{g}$. Table (4).

Regarding the results recorded in Table (5) revealed that the staphylococci count was ranged from $1.0 \times 10^{2}$ to $2 \times 10^{3}$ with a mean value of $4.3 \times 10^{2} \pm 1 \times 10^{2} \mathrm{cfu} / \mathrm{g}$ in chicken luncheon, $1.0 \times 10^{2}$ to $8 \times 10^{3}$ with a mean value of $1.6 \times 10^{3} \pm 0.42 \times 10^{3} \mathrm{cfu} / \mathrm{g}$ in chicken nuggets, and $0.5 \times 10^{2}$ to $1.0 \times 10^{4}$ with a mean value of $1.97 \times 10^{3} \pm 0.52 \times 10^{3} \mathrm{cfu} / \mathrm{g}$ in half cooked chicken shawerma, respectively.

Table (6) showed that $66.7 \%, 76.7 \%$, $80 \%$ for chicken luncheon, nuggets and half cooked chicken shawerma were recorded to be unaccepted based on total staphylococci count according to(EOS, 2005) .

Results achieved in Tables (7) indicated that Staph. aureus was detected in $23.3,30 \%$, and $46.6 \%$ of the examined samples of chicken luncheon, chicken nuggets, and half cooked chicken shawerma while E.coli was isolated from $13.3 \%, 16.6 \%$ and $23.3 \%$, of examined samples of chicken luncheon, chicken nuggets, and half cooked chicken shawerma.

Results in Tables (8) revealed that 4 E.coli (13.3\%) isolated from chicken luncheon, two of them $(50 \%)$ were Enteropathogenic E.coli $\left(\mathrm{O}_{91}: \mathrm{H}_{21}\right.$ and $\left.\mathrm{O}_{78}\right)$, one of them (25\%) was Enterotoxogenic E.coli $\left(\mathrm{O}_{128}: \mathrm{H}_{2}\right)$ and one of them $(25 \%)$ was Enteroinvasive E. coli $\left(\mathrm{O}_{124}\right)$. Moreover, 5 E.coli $(16.6 \%)$ isolated from chicken nuggets, 4 of them $(80 \%)$ were Enteropathogenic $E$. coli $\left(\mathrm{O}_{1}: \mathrm{H}_{7}(2), \mathrm{O}_{44}: \mathrm{H}_{18(1)}\right.$ and $\mathrm{O}_{78(1)}$, one of them (20\%) was Enterhaemorrhagic E. coli $\left(\mathrm{O}_{26}: \mathrm{H}_{11}\right)$. also, 7 E.coli $(23.3 \%)$ isolated from half cooked chicken shawerma, 7 of them $(100 \%)$ were Enteropathogenic E. coli $\left(\mathrm{O}_{91}: \mathrm{H}_{21}(1), \mathrm{O}_{127}: \mathrm{H}_{6}(1), \mathrm{O}_{153}: \mathrm{H}_{2}(2), \mathrm{O}_{55}: \mathrm{H}_{7}(1)\right.$, $\mathrm{O}_{44}: \mathrm{H}_{18(1)}$ and $\left.\mathrm{O}_{78(2)}\right)$.

Table (1): Statistical analytical results of Aerobic plate count (APC) (cfu/g) in the examined samples of chicken meat products $(n=30)$.

\begin{tabular}{lccc}
\hline Chicken meat products & Min & Max & Mean \pm S.E \\
\hline Chicken luncheon & $6.0 \times 10^{3}$ & $1.7 \times 10^{6}$ & $1.99 \times 10^{5} \pm 0.62 \times 10^{5}$ a \\
Chicken nuggets & $9.1 \times 10^{3}$ & $1.9 \times 10^{6}$ & $3.83 \times 10^{5} \pm 9.6 \times 10^{4}$ a \\
Chicken shawerma & $2.1 \times 10^{4}$ & $3.5 \times 10^{7}$ & $2.77 \times 10^{6} \pm 1.4 \times 10^{6}$ a \\
\hline
\end{tabular}

S.E ${ }^{*}=$ Standard error of mean.

The mean value carrying the same letter in the same column showed non significant difference. 
Table (2): Acceptability of the examined samples of chicken products based on their APC/g(n = 30).

\begin{tabular}{llllll}
\hline Chicken meat products & APC/g & \multicolumn{2}{l}{ Accepted samples } & \multicolumn{2}{l}{ Unaccepted samples } \\
\hline & & No. & $\%$ & No. & $\%$ \\
Chicken luncheon & $\geq 10^{4}$ & 6 & 20 & 24 & 80 \\
Chicken nuggets & $\geq 10^{4}$ & 2 & 6.7 & 28 & 93.3 \\
Chicken shawerma & $\geq 10^{4}$ & 0 & 0 & 30 & 100 \\
\hline
\end{tabular}

Egyptian Organization for Standardization “EOS” (2005)

Table (3): Statistical analytical results of Coliform count/g in the examined samples chicken meat products $(\mathrm{n}=30)$.

\begin{tabular}{cccc}
\hline Chicken meat products & Min & Max & Mean \pm S.E \\
\hline Chicken luncheon & $1.0 \times 10^{2}$ & $9.3 \times 10^{3}$ & $1.14 \times 10^{3} \pm 0.35 \times 10^{3 \mathrm{~b}}$ \\
Chicken nuggets & $1.0 \times 10^{2}$ & $2.3 \times 10^{4}$ & $5.0 \times 10^{3} \pm 1.2 \times 10^{3}$ ab \\
Chicken shawerma & $1.0 \times 10^{2}$ & $3.5 \times 10^{4}$ & $6.33 \times 10^{3} \pm 1.7 \times 10^{3 \mathrm{a}}$
\end{tabular}

Means of different products within the same column having different superscripts are significantly different $(\mathrm{P}<0.05)$.

Table (4): Acceptability of the examined samples of chicken products based on their Coliform count/g $(\mathrm{n}=30)$.

\begin{tabular}{lllllc}
\hline Chicken meat products & APC/g & \multicolumn{2}{l}{ Accepted samples } & \multicolumn{2}{c}{ Unaccepted samples } \\
\hline & & No. & $\%$ & No. & $\%$ \\
Chicken luncheon & $\geq 10^{2}$ & 11 & 36.7 & 19 & 63.3 \\
Chicken nuggets & $\geq 10^{2}$ & 6 & 20 & 24 & 80 \\
Chicken shawerma & $\geq 10^{2}$ & 1 & 3.3 & 29 & 96.7 \\
\hline
\end{tabular}

Egyptian Organization for Standardization "EOS” (2005)

Table (5): Statistical analytical results of Staphylococci count/g in the examined samples chicken meat products $(n=30)$.

\begin{tabular}{cccc}
\hline Chicken meat products & Min & Max & Mean \pm S.E \\
\hline Chicken luncheon & $1.0 \times 10^{2}$ & $2 \times 10^{3}$ & $4.3 \times 10^{2} \pm 1 \times 10^{2 \mathrm{~b}}$ \\
Chicken nuggets & $1.0 \times 10^{2}$ & $8 \times 10^{3}$ & $1.6 \times 10^{3} \pm 0.42 \times 10^{3}$ ab \\
Chicken shawerma & $0.5 \times 10^{2}$ & $1.0 \times 10^{4}$ & $1.97 \times 10^{3} \pm 0.52 \times 10^{3}$ a
\end{tabular}

S.E $=$ Standard error of mean

Means of different products within the same column having different superscripts are significantly different $(\mathrm{P}<0.05)$ 
Table (6): Acceptability of the examined samples of chicken products based on their Staphylococci count/g $(\mathrm{n}=30)$.

\begin{tabular}{lllll}
\hline Chicken meat products & \multicolumn{2}{l}{ Accepted samples } & \multicolumn{2}{l}{ Unaccepted samples } \\
\hline & No. & $\%$ & No. & $\%$ \\
Chicken luncheon & 10 & 33.3 & 20 & 66.7 \\
Chicken nuggets & 7 & 23.3 & 23 & 76.7 \\
Chicken shawerma & 6 & 20 & 24 & 80 \\
\hline
\end{tabular}

Egyptian Organization for Standardization "EOS" (2005)

Table (7): Prevalence of some food-borne pathogens in the examined samples of chicken meat products $(\mathrm{n}=30)$

\begin{tabular}{lcccc}
\hline Sample types & \multicolumn{2}{c}{ Staph. aureus } & \multicolumn{2}{c}{ E. coli } \\
\cline { 2 - 5 } & No. & $\%$ & No. & $\%$ \\
Chicken luncheon & & & & \\
Chicken nuggets & 7 & 23.3 & 4 & 13.3 \\
Chicken shawerma & 9 & 30 & 5 & 16.6 \\
Total (90) & 14 & 46.6 & 7 & 23.3 \\
\hline
\end{tabular}

Table (8): Incidence of identified E. coli serotypes isolated from the examined samples of chicken meat products $(n=30)$

\begin{tabular}{lcclcccc}
\hline & \multicolumn{2}{l}{$\begin{array}{l}\text { Lunchon } \\
(\mathrm{n}=4)\end{array}$} & \multicolumn{2}{l}{$\begin{array}{l}\text { Nuggets } \\
(\mathrm{n}=5)\end{array}$} & \multicolumn{2}{c}{$\begin{array}{l}\text { Shawerma } \\
(\mathrm{n}=7)\end{array}$} & $\begin{array}{c}\text { Strain } \\
\text { characteristics }\end{array}$ \\
\cline { 2 - 8 } & No & $\%$ & No & $\%$ & No & $\%$ & \\
$E$ coli $O_{91}: H_{21}$ & 1 & 25 & - & - & 1 & 14.3 & EPEC \\
$E$ coli $O_{78}$ & 1 & 25 & 1 & 20 & 2 & 28.6 & EPEC \\
$E$ coli $O_{1}: H_{7}$ & - & - & 2 & 40 & - & - & EPEC \\
$E$ coli $O_{44}: H_{18}$ & - & - & 1 & 20 & - & - & EPEC \\
$E$ coli $O_{127}: H_{6}$ & - & - & - & - & 1 & 14.3 & ETEC \\
$E$ coli $O_{153}: H_{2}$ & - & - & - & - & 2 & 28.6 & EPEC \\
$E$ coli $O_{55}: H_{7}$ & - & - & - & - & 1 & 14.3 & EPEC \\
$E$ coli $O_{128}: H_{2}$ & 1 & 25 & - & - & - & - & ETEC \\
$E$ coli $O_{124}$ & 1 & 25 & - & - & - & - & EIEC \\
$E$ coli $O_{26}: H_{11}$ & - & - & 1 & 20 & - & - & EHEC \\
Total & 4 & 100 & 5 & 100 & 7 & 100 & \\
& & & & & & & \\
\hline
\end{tabular}

$\mathrm{N}$ : number of positive E.coli samples in each group of tested products.

The percent is calculated according to number of positive E.coli samples in each group.

EPEC: Enteropathogenic E. coli EIEC: Enteroinvasive E. coli

ETEC: Enterotoxigenic E. coli $\quad$ EHEC: Enterohaemorrhagic E. coli 


\section{DISCUSSION}

In processing plants, contamination of chicken meat products can occur throughout processing, packaging and storage until the product is sufficiently cooked and consumed. Diseases can also occur when these products are not properly cooked and post-processing contaminated (Zhang et al., 2001).

The obtained results in Table (1) come in accordance with those reported by Bkheet et al. (2007) $\left(1 \times 10^{5} \mathrm{cfu} / \mathrm{g}\right.$ in chicken luncheon) and Shanab (2014) ( $4.78 \times 10^{5} \pm$ $0.51 \times 10^{5}$ and $3.89 \times 10^{5} \pm 0.46 \times 10^{5} \mathrm{cfu} / \mathrm{g}$ for chicken nuggets, and shawerma).

Higher APC is obtained by Ahmed (2004) $\left(2.18 \times 10^{6} \pm 1.36 \times 10^{6}\right.$ and $6.51 \times$ $10^{6} \pm 1.12 \times 10^{6}$ in chicken luncheon and chicken nuggets.

High APC may be attributed to the contamination of the product from different sources or unsatisfactory processing as well as unsuitable condition during storage (Zahran, 2004).

lower APC obtained by Sharaf and Sabra (2012) and Sobieh (2014) $\left(8.5 \times 10^{3}\right.$ and $4.58 \times 10^{5} \pm 0.74 \times 10^{5}$ in chicken luncheon and shawerma).

Comparing the obtained results in Table (3), higher Coliform count was obtained by Bkheet et al. (2007) $\left(3.9 \times 10^{4}\right.$ and $2.3 \times 10^{4}$ $\mathrm{cfu} / \mathrm{g}$ in chicken nuggets and chicken luncheon. Moreover, lower Coliform count obtained by El-Kewaiey (2012) $\left(2.4 \times 10^{2} \pm 8.0 \times 10 \mathrm{cfu} / \mathrm{g}\right.$ in chicken nugget $)$ and (5.08 × $10 \pm 1.61 \times 10 \mathrm{cfu} / \mathrm{g}$ in luncheon). High coliform count indicated poor hygienic quality of meat. The contamination with Coliforms may occur with soiled hands, shopping blocks or knives used for handling and cutting or contaminated water considered as a source of coliforms in meat (Yadav et al., 2006).

Nearly similar results in Table (5) were obtained by Sharaf and Sabra (2012) and Edris (2015) $\left(4.1 \times 10^{2}\right.$ and $1.81 \times 10^{3} \pm$
$0.36 \times 10^{3}$ in chicken luncheon and chicken nuggets. Higher staphylococci count in chicken luncheon obtained by Shawish (2011) and Al-Ghamdi (2012) who found that the mean value of staphylococci count are7.15 $\times$ $10^{3} \pm 2.24 \times 10^{3}$ and $1.47 \times 10^{6}$ While, higher staphylococci count was obtained by Sobieh (2014) $\left(1.74 \times 10^{4} \pm 0.31 \times 10^{4}\right.$ in chicken shawerma). Lower staphylococci count in chicken shawerma obtained by Edris (2015) $\left(3.39 \times 10^{2} \pm 0.52 \times 10^{2}\right.$ in chicken shawewrma). The high incidence of Staphylococcus spp. organisms in chicken products is an indicative of unacceptable level of contamination during handling .

The results in Table (7) were higher than obtained by Edris (2015) who isolated Staph. aureus from different chicken meat products as $5 \%, 15 \%$ and $15 \%$ for chicken luncheon, chicken nuggets, and half cooked chicken shawerma, while Shanab (2014) failed to detect Staph. aureus in the examined samples. The presence of staph. aureus in a food indicates its contamination from food handlers and inadequately cleaned equipments (ICMSF, 1996a).

E. coli is a natural inhabitant of the intestinal tracts of humans and warm-blooded animals, its presence reliably reflects fecal contamination. Moreover, it indicates a possible contamination by enteric pathogens. Undercooked or raw foodstuffs gets contamination either during primary production as slaughtering or further processing and handling e.g. cross contamination during processing, human-tofood contamination by food handlers (Adeyanju and Ishola, 2014).

E.coli was previously isolated from chicken meat products by Ahmed (2004), Awadallah et al. (2014) and Sobieh (2014) who isolated E.coli a in a percent of $26.67 \%$ from examined chicken shawerma and Edris (2015) who isolated E.coli in a percent of 
$25 \%$ of chicken nuggets and $10 \%$ of half cooked chicken shawerma.

Results in table (8) come in accordance to results obtained by Awadallah et al. (2014) who isolated 4 (10\%) E.coli from 40 samples of chicken luncheon, three of them $(7.5 \%)$ were enteropathogenic E.coli $\left(\mathrm{O}_{55}: \mathrm{K}_{59}\right)$ and one of them $(2.5 \%)$ were enterohaemorrhagic E.coli $\left(\mathrm{O}_{111}: \mathrm{K}_{58}\right)$, they also isolate $4(10 \%)$ of Staph .aureus from examined 40 samples of chicken luncheon.

Achieved results in the present study proved that most of the examined chicken meat products were contaminated with $E$. coli and Staphylococcus aureus, this considered objectionable, not only as they render the product of inferior quality and unfit for consumption but also, is considered a reliable index of fecal contamination and improper handling during processing. It is recommended to apply efficient hygienic measures during different stages of the product handling till consumer consumption.

\section{REFERENCES}

Adeyanju, G.T. and Ishola, O. (2014): Salmonella and Escherichia coli contamination of poultry meat from a processing plant and retail markets in Ibadan, Oyo State, Nigeria. Springer Plus., 3:139-147.

Ahmed, A. F. (2004): Studies on cooked meat and chicken products. PhD. Thesis (Meat Hygiene), Fac. Vet. Med., Zagazig Univ., Benha branch.

Al-Ghamdi, A.Y. (2012): Incidence of Staphylococcus aureus contamination of marketed processed chicken products with special reference to its antibiotics sensitivity collected from Al Baha city markets, Saudi Arabia. Pak. J. Food Sci., 22(3): 168-170.

American Public Health Association (APHA) (1992): Compendium methods the microbiological examination of Food. 3rd Ed. APHA, on microbiological methods for foods, Washington, D. C. USA.

Awadallah, M.A.I.; Ahmed, H.A. and Merwad, A. M. (2014): Prevalence of non- O157 shiga toxin-producing Escherichia coli and Enterotoxigenic staphylococci in ready-to-eat meat products, handlers and consumers in Cairo, Egypt. Global Veterinaria, 12 (5): 692-699.

Bkheet, A.A.; Rezk, M.S.H. and Mousa, M.M. (2007): Study on the microbiolgical content of local manufactured poultry meat products in El-Bohira governorate. Assiut Veterinary Medical Journal, 53: 115125.

Edris (2015): Bacterial and chemical investigation of some heat treated chickens meat products with special references to recent techniques. Ph.D. Thesis (Meat Hygiene), Fac. Vet. Med., Benha Univ.

El-Kewaiey, I. A. (2012): "Quality assessment of some ready to eat and locally produced chicken meat products". Assiut Vet. Med. J., 58(132): 40-45.

Edris (2015): Bacterial and chemical investigation of some heat treated chickens meat products with special references to recent techniques. Ph.D. Thesis (Meat Hygiene), Fac. Vet. Med., Benha Univ.

International Commission on Microbiological Specificans for Foods "ICMSF" (1996): Microorganisms in food, Ill-microbial specification of food pathogens. Vol.2, Chapman and Hall, London, New York.

Li, Y.; Zhuang, S.and Mustapha, A. (2005): Application of a multiplex PCR for the 
simultaneous detection of Escherichia coli O157:H7, Salmonella and Shigella in raw and ready-to-eat meat products. Meat Science, 71: 402-406.

Lyon, S.A.; Fletcher, D.L. and Berrang, M.E. (2007): Germicidal ultraviolet light to lower numbers of Listeria monocytogenes on broiler breast fillets. Poult. Sci., 86(5): 964-967.

Mensah, P.; Yeboah-Manu, D.; OwusuDarku K. and Ablordey, A. (2002): Street Food in Accra, how safe Bull. Ghana: Are they? W.H.O. 80: 546-556.

Pires, S. M.; Vieira, A. R.; Perez, E.; Wong, D. L. F. and Hald, T. (2012): Attributing human foodborne illness to food sources and water in Latin America and the Caribbean using data from outbreak investigations. Int. J. Food Microbiol., 152(3):129-38.

Ruban, S.W. and Nadeem-Fairoze (2011): Effect of Proceesing Conditions on IVlicrobiological Quality of Market Poultry Meats in Bangalore, India. J. Anim. Vet. Adv, 10 (2): I88-I91.

Shanab, M.S.M. (2014): Quality of some locally manufactured chicken meat products. M.VSC. Thesis (Meat Hygiene), Fac. Vet. Med., Benha Univ.

Sharaf, E.M and Sabra, S.M. (2012): Microbiological loads for some types of cooked chicken meat products at $\mathrm{Al}-$ Taif Governorate, KSA .World Applied Sciences Journal, 17 (5): 593-597.

Shawish, R.R.M. (2011): Microbial evaluation of some retailed cut-up chicken and poultry meat products. M. V. Sc.Thesis (Meat Hygiene), Fac. Vet. Med. Menufia Univ.

Sobieh, A.S.A. (2014): Fast meat meals safety at restaurants level in Cairo Governorate. M.VSC. Thesis (Meat
Hygiene), Fac. Vet. Med., Meat Hygiene, Benha Univ.

Soriano, J.M.; Mañes, J.; Soler, C. and Sospedra, I. (2012): Rapid whole protein quantitation of staphylococcal enterotoxins $\mathrm{A}$ and $\mathrm{B}$ by liquid chromatography/mass spectrometry. J. Chromatography A., 1238: 54-59.

Yadav, M.M.; Tale, S.; Sharda, R.; Sharma, V.; Tiwari, S. and Garg, U.K. (2006): Bacteriological quality of sheep meat in Mhow town of India. Inter. J. Food Sci. Technol., 41: 1234-1238.

Zahran, D.A. (2004): Using gamma irradiation as an option for controlling bacteria contaminating some foods of animal origin. Ph. D. Thesis (Meat Hygiene), Fac. Vet. Med., Zagazig Univ. (Banha Branch), Egypt.

Zhang, L; Davis, M.A. and Conner, D.E. (2001): Poultry-borne pathogens: plant considerations. Poultry meat processing Chap. 9. ISBN 0-8491- 0120-3, CRC Press LLC, New York, USA. 